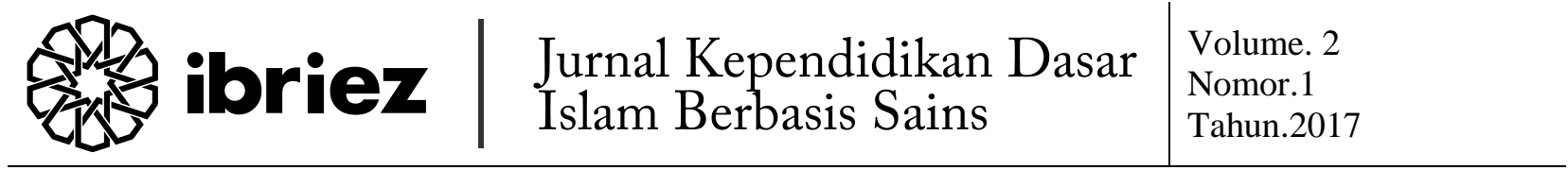

\section{Pengaruh Model Pembelajaran Student Active Learning dan Motivasi Berprestasi terhadap Kemampuan Menulis Karya Tulis Ilmiah Mahasiswa (Eksperimen pada Mahasiswa Prodi Muamalah IAIN Ponorogo)}

\author{
Lukman Hakim \\ Dosen Institut Agama Islam Negeri Ponorogo \\ Elha_men19@yahoo.co.id
}

\begin{abstract}
Abstrak
Penelitian ini bertujuan untuk mengetahui Pengaruh Metode Active Learning dan Motivasi Berprestasi terhadap Kemampuan Menulis Karya Tulis Ilmiah Mahasiswa (Eksperimen pada Mahasiswa Prodi Muamalah IAIN Ponorogo). Metode penelitian yang digunakan adalah eksperimen dengan rancangan faktorial $2 \times 2$. Populasi penelitian ini adalah semua mahasiswa Prodi Muamalah IAIN Ponorogo. Sampel diambil dengan teknik two stage random sampling. Teknik pengumpulan data yang digunakan, yaitu tes dan nontes. Teknik analisis data yang digunakan adalah ANAVA Dua Jalan. Berdasarkan analisis data disimpulkan, pertama, kemampuan menulis karya ilmiah mahasiswa yang diajar dengan metode Active Learning lebih baik daripada yang diajar dengan metode TCL (Teacher Centered Learning). Dari hasil $\mathrm{F}_{\mathrm{h}} 8.31>$ $\mathrm{F}_{\mathrm{t}}$ sebesar 4.03 dengan $\mathrm{db}$ pembilang $\mathrm{I}$ dan $\mathrm{db}$ penyebut 50 pada taraf nyata 0.05 . Kedua, kemampuan menulis karya tulis ilmiah siswa yang memiliki motivasi berprestasi tinggi lebih baik daripada kemampuan menulis karya tulis ilmiah mahasiswa yang memiliki motivasi berprestasi rendah. Dari hasil $\mathrm{F}_{\mathrm{h}}$ sebesar $13.53>\mathrm{F}_{\mathrm{t}}$ sebesar 4.03 dengan db pembilang $\mathrm{I}$ dan $\mathrm{db}$ penyebut 50 pada taraf nyata 0.05 . Ketiga, ada interaksi antara metode pembelajaran dan motivasi berprestasi terhadap kemampuan menulis karya ilmiah. Dari hasil $F_{h}$ sebesar $5.82>F_{t}$ sebesar 4.03 dengan $\mathrm{db}$ pembilang I dan db penyebut50 pada taraf nyata 0.05 .
\end{abstract}

Keywords: Metode Active Learning, Metode Teacher Centered Learning, Motivasi Berprestasi, Menulis Karya tulis Ilmiah. 


\begin{abstract}
The objective of this research is to investigate the effect of the Active learning method and the achievement motivation on the students' ability to compose scientific Researh (An Experiment on the Students in Prodi Muamalah IAIN Ponorogo). This research used the experimental research method with the factorial design of $2 \times 2$. Its population was all of the students of Prodi Muamalah IAIN Ponorogo. The samples of research were taken by using the two-stage random sampling technique. The data of research were collected through test and non-test. They were analyzed by using the two-way analysis of variance. The results of research show that: (1) the students instructed with the active learning method have a better ability to compose scientific Researh than those instructed with the Teacher Centered learning method as indicated by the value of $F_{h}=8.31$ which was greater than that of $F_{t}=$ 4.03 with the numerator DF I and the denominator DF = 50 at the real significance $=0.05$; (2) the students with the high achievement motivation have a better ability to compose scientific Researh than those with the low achievement motivation as shown by the value of $F_{h}=13.53$ which was greater than that of $F_{t}=4.03$ with the numerator DF I and the denominator DF = 50 at the real significance $=0.05$; and (3) there is an interaction between the learning methods and the achievement motivations on the students' ability to compose the scientific Researh as pointed out by the value of $F_{h}=5.82$ which was greater than that of $F_{t}=4.03$ with the numerator DF I and the denominator DF $=50$ at the real significance of 0.05 .
\end{abstract}

Keywords: Learning Method of Inquiry, Learning Method of ENE, Achievement Motivation, The Competence of Description Writing.

\section{A. PENDAHULUAN}

Pendidikan telah mengalami perkembangan seiring dengan kemajuan teknologi dan ilmu pengetahuan. Keberhasilan pendidikan ditentukan oleh banyak hal, diantaranya model, strategi, dan sarana prasarana. Faktor tersebut memiliki fungsi, yaitu mempermudah pengajar dalam menyampaikan kompetensi dasar pada setiap mata pelajaran. Akan tetapi, proses belajar mengajar di kelas tetap ditentukan oleh cara mengajar dosen dan peran serta mahasiswa sebagai individu-individu yang terlibat langsung dalam proses tersebut. Sebagai sutradara dalam proses belajar mengajar, dosen selayaknya memberikan skenario yang kreatif dan inovatif dalam kegiatan belajar. Oleh karena itu, kemampuan serta kesiapan dosen dalam mengajar memegang peranan penting bagi keberhasilan proses belajar mengajar pada mahasiswa. Kesiapan dosen tidak terlepas dari model yang digunakan, media pembelajaran, dan sarana pendukung lain yang digunakan dalam kegiatan belajar. Hal ini memperlihatkan terdapat keterkaitan antara proses belajar di kelas dengan prestasi belajar mahasiswa.

Pada dasarnya manusia adalah makhluk pebelajar. Dari waktu ke waktu, segala aspek kehidupan manusia semakin baik. Proses dari tidak tau menjadi tau, dari tidak baik menjadi baik merupakan hasil dari evaluasi yang berkesinambungan. Hal itu juga berlaku pada pendidikan. Semua komponen pendidikan akan terus berkembang. Setiap kegiatan pendidikan yang berlangsung melibatkan seluruh 
komponen pendidikan tersebut. Prayitno menyatakan bahwa dalam pendidikan terdapat komponen pendidikan, diantaranya peserta didik, pendidik, tujuan pendidikan, dan proses pembelajaran. Kualitas komponen tersebut sejalan dengan kualitas pendidikan yang diharapkan. ${ }^{1}$ Begitu juga dengan strategi dosen dalam penyelenggaraan pendidikan, semakin kreatif dan efektif, maka keberhasilan pendidikan dapat diperoleh. Model belajar merupakan inovasi agar proses belajar menjadi lebih menyenangkan. Sedangkan sebagai sumber belajar, model merupakan sarana bagi mahasiswa untuk memperoleh informasi dan ilmu pengetahuan sebanyak-banyaknya. Tujuan pembelajaran dapat tercapai bergantung pada beberapa aspek, salah satu aspek terpenting adalah cara dosen dalam mengonsep pembelajaran dan penyampaian yang efektif. Penelitian yang dilakukan Moghadam dan Malekzadeh yang berjudul "Improving L2 Writing Ability in The Light of Critical Thinking" menyatakan dosen hendaknya menggunakan pendekatan yang tepat untuk meningkatkan kemampuan menulis. $^{2}$ Kesulitan yang dihadapi mahasiswa dalam menulis, seperti keterbatasan kosa kata, kesulitan dalam bernalar, dan kurangnya pengetahuan tentang pentingnya menulis akan menimbulkan rasa malas dan kurang minat menulis. Maka dari itu, pendekatan yang tepat sangat diperlukan untuk memecahkan masalah ini.

\footnotetext{
${ }^{1}$ Prayitno, Dasar teori dan praksis pendidikan.

${ }^{2}$ Moghaddam dan Malekzadeh, "Improving L2 writing ability in the light of critical thinking."
}

Kenyataan yang ada saat kini, kegiatan belajar mengajar masih berpusat pada dosen. Di kelas, dosen masih memiliki peran yang dominan dalam kegiatan belajar. Dengan teknik seperti ini, mahasiswa menjadi pasif yang akan mengakibatkan kompetensi dasar setiap mata pelajaran tidak tercapai. Begitu juga dengan pembelajaran menulis. Paradigma seperti ini sudah selayaknya dihilangkan. Peran dosen di kelas harus mulai dikurangi dan mahasiswa harus diberi peras aktif dalam kegiatan belajar di kelas. Dosen menjadi fasilitator dengan membuat strategi belajar yang efektif. salah satunya dengan menggunakan model Student Active Learning.

Pembelajaran active learning merupakan suatu pembelajaran yang menekankan pada proses keterlibatan mahasiswa secara penuh untuk dapat menemukan materi yang dipelajari dan menghubungkannya dengan situasi kehidupan nyata, sehingga mereka dapat menemukan fenomena dalam kehidupan sekitar dan menuliskannya dalam suatu karya. Dari konsep tersebut ada dua hal yang perlu dipahami. Pertama,active learning menekankan pada proses keterlibatan siswa untuk menemukan materi. Artinya proses belajar diorientasikan pada proses pengalaman secara langsung. Proses belajar dalam konteks active learning, tidak mengharapkan mahasiswa hanya menerima pelajaran tetapi proses aktif mencari dan menemukan materi pelajaran.

Kedua, motivasi berprestasi yang dimiliki mahasiswa memiliki peran penting dalam hasil belajar yang ingin 
dicapai. Bahkan dapat diasumsikan mahasiswa yang memiliki motivasi tinggi dapat mengikuti pelajaran dengan baik walaupun dengan berbagai macam strategi belajar yang digunakan oleh dosen. Motivasi dapat diartikan sebagai daya penggerak yang menjadi aktif pada saat melakukan kegiatan. ${ }^{3}$ Mahasiswa yang memiliki motivasi tinggi untuk berprestasi memiliki kecenderungan aktif, kreatif, cekatan, dan fokus. Penelitian yang dilakukan Ming et al. dengan judul "Attitude and Motivation If Malaysia Secondary Studies Forward Learning as A Secondary Language: A Care Study" menyatakan bahwa motivasi berpengaruh terhadap hasil belajar mahasiswa. ${ }^{4}$

Prestasi yang maksimal menjadi tujuan mahasiswa sehingga persaingan untuk menjadi lebih baik dari mahasiswa lain menjadi tolok ukur dalam bekerja. Motivasi berprestasi memudahkan mahasiswa untuk memperoleh kemampuan yang diharapkan.

Tujuan dari pendidikan adalah membuat peserta didik, dalam hal ini mahasiswa, memiliki kemampuankemampuan yang sesuai dengan kebutuhannya sebagai bekal memasuki dunia setelah sekolah. Salah satu kemampuan yang harus dikuasai mahasiswa adalah kemampuan menulis. Suharno, dkk mengartikan kemampuan sebagai kemampuan proses, yaitu yang diperoleh dari suatu latihan kemampuankemampuan mental, fisik, dan sosial yang

\footnotetext{
${ }^{3}$ Soemarsono, Strategi Belajar Mengajar.

${ }^{4}$ Thang, Ting, dan Jaafar, "Attitudes and motivation of Malaysian secondary students towards learning English as a second language," 51-52.
}

mendasar sebagai penggerak kemampuankemampuan yang lebih tinggi. ${ }^{5}$

Menulis merupakan proses penyaluran informasi dalam bentuk tulisan. Andayani menyatakan menulis adalah menurunkan atau melukiskan lambang-lambang grafik yang menggambarkan suatu bahasa yang dipahami oleh seseorang sehingga orang lain dapat membaca langsung lambanglambang grafik tersebut. ${ }^{6}$ Kemampuan menulis sebagai salah satu aspek berbahasa merupakan suatu hal yang sangat penting diajarkan pada mahasiswa. Kegiatan menulis merupakan kegiatan menggali pikiran dan perasaan mengenai suatu objek, memilih hal-hal yang akan ditulis, menentukan bagaimana cara menulis, sehingga pembaca dapat memahami dengan mudah dan jelas. Kalau diamati secara cermat, banyak mahasiswa yang memiliki keinginan belajar menulis, namun tidak semua mahasiswa memiliki kemampuan menulis dengan baik, sehingga apa yang ditulis seringkali tidak mudah untuk dimengerti dan dipahami orang lain. Untuk mengatasi masalah ini, tidak ada cari lain selain melakukan kegiatan menulis sebanyak banyaknya. Semakin banyak menulis maka kemampuan menulis akan meningkat dengan sendirinya.

Salah satu kemampuan yang harus dimiliki mahasiswa adalah menulis karya ilmiah. Karya tulis ilmiah merupakan karya tulis yang isinya berusaha memaparkan suatu pembahasan secara ilmiah yang dilakukan oleh seorang penulis atau peneliti. Pada prinsipnya semua karya ilmiah adalah hasil dari suatu

\footnotetext{
${ }^{5}$ Suharno et al., Belajar Dan Pembelajaran II.

${ }^{6}$ Andayani, Problema dan Aksioma, 191.
} 
kegiatan ilmiah. Dalam hal ini, yang membedakan hanyalah materi, susunan, tujuan, serta panjang pendeknya karya tulis ilmiah tersebut. Kemampuan menulis mahasiswa yang masih dikatakan kurang memiliki implikasi terhadap terbatasnya karya tulis yang telah mahasiswa buat. Karya ilmiah sederhana seperti membuat paper atau makalah pun mahasiswa masih belum menguasai secara benar, baik tata tulis maupun bahasa yang digunakan. Berdasarkan beberapa temuan di lapangan, ternyata terdapat kenyataan bahwa kemampuan dan minat mahasiswa dalam menulis karya ilmiah masih sangat rendah. Ini bisa dibuktikan, yaitu 1) terbatasnya jumlah mahasiswa yang menerapkan teori penulisan karya ilmiah yang dilatih dosen di kelas; 2) terbatasnya jumlah karya mahasiswa dalam bentuk tulisan baik dalam bentuk majalah dinding (mading) maupun dalam lomba menulis; 3) kurang tertariknya mahasiswa dalam kegiatan menulis; 4) anggapan menulis itu sukar; 6) dosen kurang bersemangat dalam pembelajaran menulis karya ilmiah karena mahasiswa kurang tertarik.

Berdasarkan hal tersebut, dianggap perlu diterapkan pendekatan pembelajaran yang tepat untuk meningkatkan kemampuan menulis karya tulis ilmiah mahasiswa. Model Student Active Learning merupakan alternatif pilihan. Model pembelajaran Student Active Learning diharapkan sebagai terapi strategis yang dapat menunjang ketercapaian standar kemampuan menulis karya ilmiah mahasiswa Prodi Muamalah semester 1 IAIN Ponorogo. Dengan mengondisikan mahasiswa aktif dalam pembelajaran akan memancing kreatifitas mahasiswa. Pada penelitian ini menggunakan sampel Semester 1 dengan pertimbangan mahasiswa sudah memiliki bahan apersepsi yang cukup dari materi yang diajarkan di SMA/sederajad serta bertepatan dengan mahasiswa mendapatkan mata kuliah bahasa Indonesia yang di dalamnya meliputi penulisan karya ilmiah.

\section{B. MODEL PENELITIAN}

Model penelitian yang digunakan dalam penelitian ini adalah eksperimen dengan rancangan faktorial $2 \times 2$. Pendapat ini merujuk pada pendapat. $^{7}$ Penelitian dilaksanakan di IAIN Ponorogo kelas Muamalah D Semester 1 (sebagai kelas eksperimen) dan kelas Muamalah G (sebagai kelas kontrol). Pengambilan sampel menggunakan teknik two stage random sampling. Pertama secara Purposive Sampling, kemudian dilanjutkan dengan Random Sampling. Teknik pengumpulan data menggunakan tes dan nontes. Menulis karya ilmiah diukur dari tes menulis karya ilmiah. Motivasi berprestasi diukur dengan angket menggunakan skala. ${ }^{8}$ Penelitian ini menggunakan analisis data deskriptif. Adapun yang akan diperoleh pada analisis data secara deskriptif mencakup perhitungan rerata (mean), modus, median, simpangan baku, varian, dan pembuatan daftar distribusi frekuensi, histogram. Uji persyaratan meliputi uji normalitas dengan teknik Lillifors, sedangkan uji homogenitas menggunakan teknik Bartlett.Uji persyaratan tersebut

\footnotetext{
${ }^{7}$ Suharsimi, Prosedur Penelitian Suatu Pendekatan Praktek, 377.

${ }^{8}$ Andayani, Statistik: untuk Pembelajaran Bahasa, 23.
} 
dilakukan pada masing-masing kolom, baris, dan sel. Penggunaan analisis data inferensi untuk menguji hipotesis digunakan statistik ANAVA dua jalan. Dilanjutkan uji lanjut dengan uji Scheffe.

\section{HASIL PENELITIAN}

Penilaian dalam penulisan karya ilmiah dalam penelitian ini, meliputi 1) Kelengkapan isi sesuai dengan judul (poin 30); 2) Kekohesian dan kekoherenan (poin 20); 3) Sistematika (poin 20); 4) Reverensi (poin 15); 5) Kesesuaian ejaan dan tanda baca (15).

Selain itu indikator yang digunakan dalam angket motivasi berprestasi, meliputi 1) Berusaha unggul, 2) Menyelesaikan tugas dengan baik, 3) Rasional dalam meraih keberhasilan dan berprasangka baik terhadap teman yang berhasil, 4) Menyukai tantangan, 5) Menerima tanggung jawab pribadi untuk sukses, 6) Menyukai suatu pekerjaan dengan tanggung jawab pribadi, umpan balik, dan resiko tingkat menengah.

Data kemampuan menulis karya ilmiah, yaitu (1) skor menulis karya ilmiah mahasiswa yang diajar dengan model pembelajaran Student Active Learning(A1) tanpa membedakan motivasi berprestasi, dari rentang 24 mahasiswa diperoleh nilai terendah 67.5, dan nilai tertinggi 92.5. Kemampuan menulis karya ilmiah untuk kelompok ini mempunyai (mean) atau nilai rata-rata sebesar 82.19 , nilai modus sebesar 87.5, nilai median sebesar 83.75, varian sebesar 57.78, dan simpangan baku (standar deviasi) sebesar 7.601. Kemudian dibuat gambar histogram dan poligon frekuensi nilai kemampuan menulis karya ilmiah.

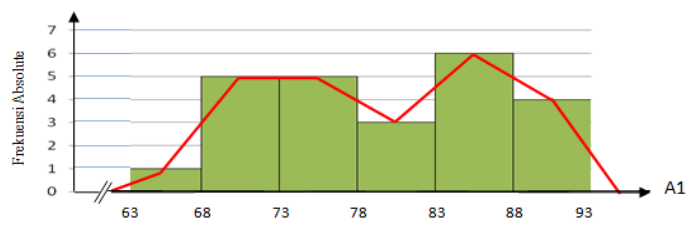

Gambar 1, Histogram dan polygon frekuensi nilai kemampuan menulis karya ilmiah yang diajar. dengan model Active Learning

(2) skor menulis karya ilmiah mahasiswa yang diajar dengan model TCL (A2) tanpa membedakan motivasi berprestasi, dari rentang 30 mahasiswa diperoleh nilai terendah 66.25, dan nilai tertinggi 87.5. Kemampuan menulis karya ilmiah untuk kelompok ini mempunyai (mean) atau nilai rata-rata sebesar 77.58 , nilai modussebesar 80, nilai median sebesar 77.5, varian sebesar 36.74, dan simpangan baku (standar deviasi) sebesar 6.06. Kemudian dibuat gambar histogram dan poligon frekuensi nilai kemampuan menulis deskripsi.

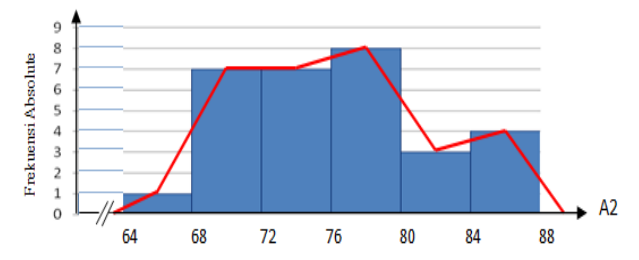

Gambar 2. Histogram dan polygon frekuensi nilai kemampuan menulis karya ilmiah yang diajar dengan model TCL

(3) skor menulis deskripsi mahasiswa yang memiliki motivasi berpretasi tinggi (B1) dari rentang 26 mahasiswa diperoleh nilai terendah 71.25, dan nilai tertinggi 92.5. Kemampuan menulis deskripsi untuk kelompok ini mempunyai (mean) atau nilai rata-rata sebesar 83.28 , nilai modus sebesar 87.5, nilai median sebesar 83.125, varian sebesar 36.66, dan simpangan baku (standar deviasi) sebesar 6.05. Kemudian 
dibuat gambar nilai histogram frekuensi nilai kemampuan menulis deskripsi

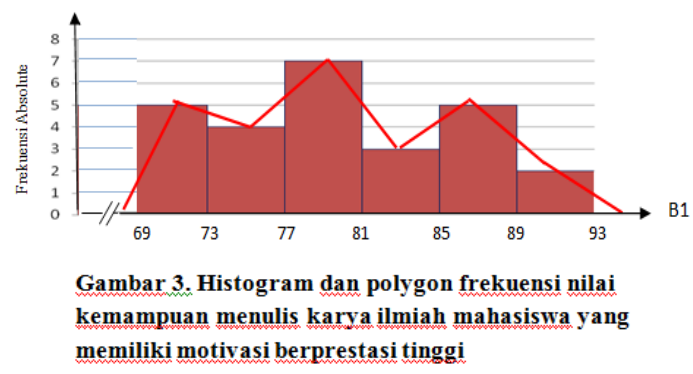

(4) skor menulis karya ilmiah mahasiswa yang memiliki motivasi berpretasi rendah (B2) dari rentang 28 mahasiswa diperoleh nilai terendah 66.25 , dan nilai tertinggi 87.5. Kemampuan menulis karya ilmiah untuk kelompok ini mempunyai (mean) atau nilai rata-rata sebesar 76.43 , nilai modus sebesar 80 , nilai median sebesar 75 , varian sebesar 45.11, dan simpangan baku (standar deviasi) sebesar 6.72. Kemudian dibuat gambar histogram dan poligon frekuensi nilai kemampuan menulis karya ilmiah.

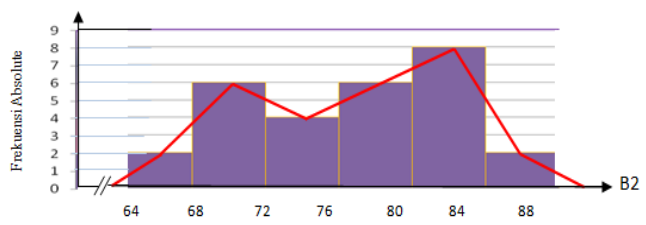

Gambar 4. Histogram dan polygon frekuensi nilai kemampuan menulis karya ilmiah mahasiswa yang memiliki motivasi berprestasi rendah

(5) skor menulis karya ilmiah mahasiswa yang diajar dengan model Student Active Learning yang memiliki motivasi berprestasi tinggi, dari rentang 11 mahasiswa diperoleh nilai terendah 80, dan nilai tertinggi 92.5. Kemampuan menulis karya ilmiah untuk kelompok ini mempunyai (mean) atau nilai rata-rata sebesar 86.70, nilai modus sebesar 87.5, nilai median sebesar 87.5, varian sebesar 25.40, dan simpangan baku (standar deviasi) sebesar 5.04. Kemudian dibuat gambar histogram dan poligon frekuensi nilai kemampuan menulis karya ilmiah.

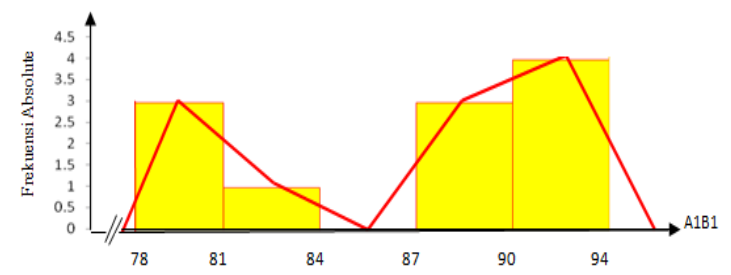

Gambar 5. Histogram dan polygon frekuensi nilai kemampuan menulis karya ilmiah yang diajar dengan model Active Learning dan motivasi berprestasi tinggi

(6) skor menulis karya ilmiah mahasiswa yang diajar dengan model Student Active Learning yang memiliki motivasi berprestasi rendah, dari rentang 13 mahasiswa diperoleh nilai terendah 67.5, dan nilai tertinggi 87.5. Kemampuan menulis karya ilmiah untuk kelompok ini mempunyai (mean) atau nilai rata-rata sebesar 78.37, nilai modus sebesar 71.25, nilai median sebesar 80 , varian sebesar 55.05, dan simpangan baku (standar deviasi) sebesar 7.42. Kemudian dibuat gambar histogram dan poligon frekuensi nilai kemampuan menulis karya ilmiah.

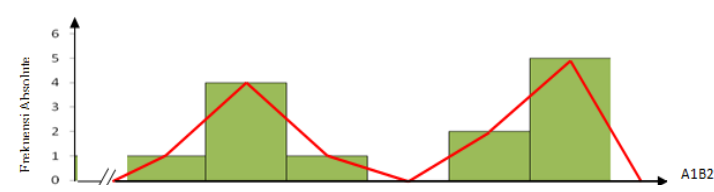

Gambar 6. Histogram dan polygon frekuensi nilai kemampuan menulis karya ilmiah yang diajar dengan model Active Learning dan motivasi berprestasi rendah

(7) skor menulis karya ilmiah mahasiswa yang diajar dengan model TCL yang memiliki motivasi berprestasi tinggi, dari rentang 15 mahasiswa diperoleh nilai terendah 71.25, dan nilai tertinggi 87.5. Kemampuan menulis karya ilmiah untuk kelompok ini mempunyai (mean) atau 
nilai rata-rata sebesar 80.38 , nilai modus sebesar 87.5, nilai median sebesar 80, varian sebesar 29.27, dan simpangan baku (standar deviasi) sebesar 5.41.Kemudian dibuat gambar histogram dan poligon frekuensi nilai kemampuan menulis karya ilmiah.

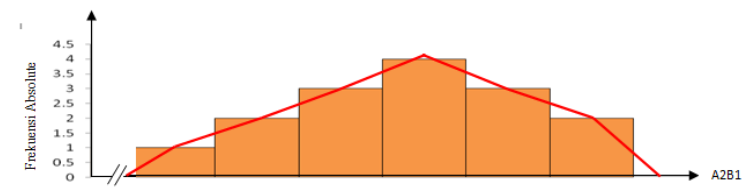

Gambar 7. Histogram dan polygon frekuensi nilai kemampuan menulis karya ilmiah yang diajar dengan model TCL dan motivasi berprestasi tinggi

(8) Skor menulis karya ilmiah mahasiswa yang diajar dengan model TCL yang memiliki motivasi berprestasi tinggi, dari rentang 15 mahasiswa diperoleh nilai terendah 66.25, dan nilai tertinggi 87.5. Kemampuan menulis karya ilmiah untuk kelompok ini mempunyai (mean) atau nilai rata-rata sebesar 74.75 , nilai modus sebesar 80 , nilai median sebesar 75 , varian sebesar 33.30, dan simpangan baku (standar deviasi) sebesar 5.77.Kemudian dibuat gambar histogram dan poligon frekuensi nilai kemampuan menulis karya ilmiah.

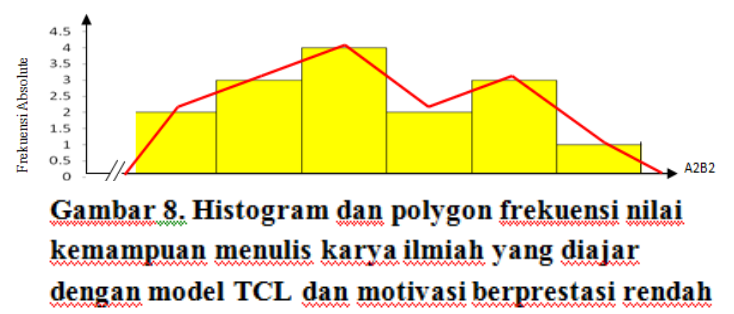

Pengijian normalitas data dalam kelompok penelitian ini dilakukan terhadap delapan kelompok data. Pengujian ini dimaksudkan untuk menguji hipotesis nol $\left(\mathrm{H}_{0}\right)$ melawan hipotesis tandingan $\left(\mathrm{H}_{1}\right)$ pada taraf nyata 0,05 . Signifikansi nilai $\mathrm{L}_{0}$ dibandingkan dengan dengan nilai $\mathrm{L}_{\mathrm{t} .}$ Jika nilai $\mathrm{L}_{0}$ kurang dari $\mathrm{L}_{\mathrm{t}}$, maka $\left(\mathrm{H}_{0}\right)$ diterima; $\left(\mathrm{H}_{1}\right)$ ditolak. Dan
sebaliknya.Adapun pengelompokan hasil uji lilliefors ditampilkan dalam tabel berikut.

\section{Tabel 1.Rekapitulasi Hasil Uji Hipotesis untuk Uji Normalitas}

Pengujian homogenitas varians dilakukan untuk menguji kesamaan variansi nilai kemampuan menulis karya ilmiah berdasar kelompok-kelompok nilai yang ada pada tiap masing-masing kolom, baris, dan maisngmasing sel.

\begin{tabular}{|c|c|c|c|c|c|c|}
\hline Variabel & $\mathrm{N}$ & Mean & sd & $\mathrm{L}$ & $\begin{array}{c}\text { Ltabe } \\
\mathrm{l}\end{array}$ & Tes \\
\hline $\mathrm{A} 1$ & 24 & 82.19 & 7.60 & 0.133 & 0.176 & normal \\
$\mathrm{A} 2$ & 30 & 77.58 & 6.06 & 0.087 & 0.161 & normal \\
$\mathrm{B} 1$ & 26 & 83.28 & 6.05 & 0.129 & 0.171 & normal \\
$\mathrm{B} 2$ & 28 & 76.43 & 6.72 & 0.149 & 0.166 & normal \\
$\mathrm{A} 1 \mathrm{~B} 1$ & 11 & 86.70 & 5.04 & 0.181 & 0.249 & normal \\
$\mathrm{A} 1 \mathrm{~B} 2$ & 13 & 78.37 & 7.42 & 0.216 & 0.234 & normal \\
$\mathrm{A} 2 \mathrm{~B} 1$ & 15 & 80.38 & 5.41 & 0.111 & 0.220 & normal \\
A2B2 & 15 & 74.75 & 5.77 & 0.128 & 0.220 & normal \\
\hline
\end{tabular}

Pengujian dimaksudkan untuk menguji hipotesis nol $\left(\mathrm{H}_{0}\right)$ melawan hipotesis tandingan $\left(\mathrm{H}_{1}\right)$ pada taraf nyata 0,05 . Kriteria penilaian yang dilakukan ialah $\left(\mathrm{H}_{0}\right)$ diterima jika ternyata harga $x^{2}$ hitung lebih kecil atau sama dengan $x^{2}$ tabel. Sebaliknya, jika harga $\mathrm{x}^{2}$ hitung $>\mathrm{x}^{2}$ tabel. Pada taraf nyata 0,05 maka $\left(\mathrm{H}_{\mathrm{i}}\right)$ yang menyatakan bahwa varians skor tidak homogen diterima.

Tabel 2. Rangkuman hasil uji homogenitas varians

\begin{tabular}{|c|l|l|l|}
\hline Kelompok & \multicolumn{2}{|l|}{ bartlett } & Keterangan \\
\hline$\mu \mathrm{A}_{1}: \mu \mathrm{A}_{2}$ & 1.324 & 3.84 & Homogen \\
\hline$\mu \mathrm{B}_{1}: \mu \mathrm{B}_{2}$ & 0.276 & 3.84 & Homogen \\
\hline$\mu \mathrm{A}_{1} \mu \mathrm{B}_{1}: \mu \mathrm{A}_{1} \mu \mathrm{B}_{2}$ & 1.56 & 3.84 & Homogen \\
\hline$\mu \mathrm{A}_{1} \mu \mathrm{B}_{1}: \mu \mathrm{A}_{2} \mu \mathrm{B}_{1}$ & 0.058 & 3.84 & Homogen \\
\hline$\mu \mathrm{A}_{1} \mu \mathrm{B}_{1}: \mu \mathrm{A}_{2} \mu \mathrm{B}_{2}$ & 0.21 & 3.84 & Homogen \\
\hline$\mu \mathrm{A}_{1} \mu \mathrm{B}_{2}: \mu \mathrm{A}_{2} \mu \mathrm{B}_{1}$ & 1.289 & 3.84 & Homogen \\
\hline$\mu \mathrm{A}_{1} \mu \mathrm{B}_{2}: \mu \mathrm{A}_{2} \mu \mathrm{B}_{2}$ & 0.817 & 3.84 & Homogen \\
\hline$\mu \mathrm{A}_{2} \mu \mathrm{B}_{1}: \mu \mathrm{A}_{2} \mu \mathrm{B}_{2}$ & 0.058 & 3.84 & Homogen \\
\hline
\end{tabular}


Pengujian hipotesis penelitian diuji dengan teknik Analisis Varians Dua Jalan.Teknik analisis statistik tersebut digunakan untuk melihat perbedaan pengaruh perlakuan secara keseluruhan, yaitu (1) kemampuan menulis karya ilmiah mahasiswa yang diajar dengan model Student Active Learning lebih baik daripada kemampuan menulis karya ilmiah mahasiswa yang diajar dengan model TCL, (2) kemampuan menulis karya ilmiah mahasiswa yang memiliki motivasi berprestasi tinggi lebih baik daripada kemampuan menulis karya ilmiah mahasiswa yang memiliki motivasi berprestasi rendah, (3) ada interaksi antara model pembelajaran dan motivasi berprestasi.

Tabel 3. Perhitungan anava dua jalan

\begin{tabular}{|c|c|c|c|c|c|}
\hline $\begin{array}{c}\text { Sumber } \\
\text { Variansi }\end{array}$ & Db & JK & RJK & $\mathrm{F}$ & $\begin{array}{c}\mathrm{F} \\
\text { tabel }\end{array}$ \\
\hline Model (A) & 1 & 282.645 & 282.645 & 8.31 & 4.03 \\
\hline $\begin{array}{c}\text { Motivasi } \\
\text { berprestasi } \\
\text { (B) }\end{array}$ & 1 & 495.889 & 495.889 & 13.53 & 4.03 \\
\hline $\begin{array}{c}\text { Interaksi } \\
\text { (AxB) }\end{array}$ & 1 & 198.48 & 198.48 & 5.82 & 4.03 \\
\hline Dalam & 50 & 1699.95 & 33.99 & & \\
\hline Total & 53 & 2676.97 & & & \\
\hline
\end{tabular}

Hasil pembahasan dalam penelitian ini secara terperinci diuraikan sebagai berikut.

Pertama, kemampuan menulis karya ilmiah mahasiswa yang diajar dengan model Student Active Learning lebih baik daripada kemampuan menulis karya ilmiah mahasiswa yang diajar dengan model TCL. Menunjukan hasil Fh > $F_{t}$, yaitu, $8.31>4.03$. kemudian, hasil analisis deskripsi diperoleh skor rata-rata mahasiswa yang diajar dengan model Student Active Learning adalah 82.19.Sedangkan Skor rata-rata mahasiswa yang diajar dengan model TCL adalah 77.58. Dilihat dari hasil analisi anava dua jalan dan skor rata-rata yang dihasilkan, kemampuan menulis karya ilmiah mahasiswa yang diajar dengan model Student Active Learning lebih baik daripada yang diajar dengan menggunakan model TCL.

Penelitian ini tentunya memiliki perbandingan dengan penelitian yang dilakukan oleh peneliti lain sebelumnya, untuk melihat efek dari eksperimen yang dilakukan. Penelitian ini Senada dengan penelitian Asna yang menerapkan model Student Active Learning. ${ }^{9}$ Kelompok mahasiswa yang diajar dengan model pembelajaran Student Active Learning masuk dalam kategori baik, dengan memperoleh nilai rata-rata kelas eksperimen (model Student Active Learning) sebesar 7,14. Nilai rata-rata kelas kontrol (model konvensional) sebesar 6,8. Pembaharuan terletak pada penggunaan kelas kontrol yang dalam penelitian ini menggunakan model dengan istilah Teacher Active Learning dalam mempengaruhi kemampuan menulis karya ilmiah mahasiswa. Melalui perbandingan ini dapat ditemukan bahwa penerapan metode active learning sangat berpengaruh terhadap tercapainya kompetensi pembelajaran menulis dalam berbagai tingkatan. Dengan melihat penelitian ini mengambil objek penelitian mahasiswa semester 1. Sedangkan penelitian yang dilakukan Hasna mengambil objek siswa kelas 5 tingkat dasar.

\footnotetext{
${ }^{9}$ Asna, "IMPLEMENTASI STRATEGI PEMBELAJARAN BERBASIS INKUIRI DENGAN SIKLUS BELAJAR 5E UNTUK MENINGKATKAN KETERAMPILAN BERPIKIR KRITIS."
} 
Kemudian Effendi, menggunakan model active learning dan internet-based learning dalam proses pembelajaran di perguruan tinggi. ${ }^{10}$ Dari penelitian yang telah dilakukan dapat diperoleh hasil bahwa integrasi metode active learning dan internet-based learning dapat meningkatkan keaktifan dan kreativitas belajar mahasiswa di perguruan tinggi. Perbedaan penelitian ini dengan penelitian yang dilakukan oleh Effendi, yaitu hasil yang diperoleh. Pada penelitian ini peneliti berusaha memaparkan hasil belajar mahasiswa dengan dengan menggunakan rancangan penelitian vaktorial $2 \times 2$ dengan teknik analisis data menggunakan anava dua jalan, untuk menunjukan perbedaan dan interaksi antar variabel. Sedangkan penelitian yang dilakukan Effendi hanya memaparkan hasil penelitiannya dengan metode deskriptif kualitatif. Penulis berasumsi bahwa penelitian eksperimen lebih cocok menggunakan metose kuantitatif daripada kualitatif. Namun demikian, hasil yang diperoleh ternyata sama, yaitu menunjukan metode active learning secara siknifikan berpengaruh terhadap hasil belajar mahasiswa.

Kedua, kemampuan menulis karya ilmiah mahasiswa yang memiliki motivasi berprestasi tinggi lebih baik daripada kemampuan menulis karya ilmiah mahasiswa yang memiliki motivasi berprestasi rendah. .hasil perhitungan anava dua jalan menunjukan hasil $\mathrm{Fh}>\mathrm{F}_{\mathrm{t}}$, yaitu, $13.53>$ 4.03. kemudian, hasil analisis deskriptif menunjukan bahwa

\footnotetext{
${ }^{10}$ Effendi, "Integrasi Pembelajaran Active Learning dan Internet-Based Learning dalam Meningkatkan Keaktifan dan Kreativitas Belajar,” 283.
}

skor rata-rata menulis karya ilmiah mahasiswa yang memiliki motivasi berprestasi tinggi tanpa membedakan model pembelajaran yang diajarkan memperoleh nilai rata-rata sebesar 83,28. Sedangkan skor rata-rata menulis karya ilmiah mahasiswa yang memiliki motivasi berprestasi rendah tanpa membedakan model pembelajaran yang diajarkan memperoleh nilai rata-rata sebesar 76,43. Dilihat dari hasil analisi anava dua jalan dan skor rata-rata yang dihasilkan, kemampuan menulis karya ilmiah mahasiswa yang memiliki motivasi berprestasi tinggi lebih baik daripada yang memiliki motivasi berprestasi rendah.

Sejalan dengan penelitian Gupta and Getachew dalam penelitiannya menunjukan motivasi mempengaruhi sikap mahasiswa terhadap pembelajaran, khususnya pembelajaran menulis. ${ }^{11}$ Hasil belajar mahasiswa yang memiliki motivasi tinggi lebih baik daripada hasil belajar mahasiswa yang memiliki motivasi rendah. Persamaan penelitian ini dengan peneliaian yang terdahulu terletak pada penggunaan variabel motivasi berprestasi. Sedangkan pembaharuannya, penelitian terdahulu menggunakan variabel menulis di tingkat perguruan tinggi. Zubairi dan Sarudin dalam penelitiannya juga memperlihatkan mahasiswa yang memiliki motivasi tinggi akan memiliki sikap positif terhadap pembelajaran. ${ }^{12}$ Pembaharuannya adalah penelitian terdahulu menggunakan objek yang luas, yaitu mahasiswa di Malaysia.Sedangkan

\footnotetext{
${ }^{11}$ Gupta dan Woldemariam, "The influence of motivation and attitude on writing strategy use of undergraduate EFL students."

${ }^{12}$ Zubairi dan Sarudin, "Motivation to learn a foreign language in Malaysia," 73-87.
} 
penelitian ini hanya digunakan pada mahasiswa IAIN Ponorogo .Kemudian Chua Siew Lian dalam penelitiannya menyatakan bahwa motivasi memiliki peranan dalam meningkatkan hasil belajar. ${ }^{13}$ Persamaan dalam penelitian ini terletak pada pengaruh motivasi terhadap hasil belajar.

Ketiga, terdapat interaksi antara model Pembelajaran dan motivasi berprestasi terhadap keterampilan menulis karya ilmiah mahasiswa Prodi Muamalah IAIN Ponorogo. Berdasarkan perhitungan diperoleh nilai $\mathrm{F}_{\mathrm{h}}=5.82$ lebih besar dari nilai $\mathrm{Ft}=4.03$.

Kemudian dilakukan uji lanjut dengan menggunakan uji Scheffe yang menujukan ada interaksi antar sel (A1B1)(A1B2) bahwa mahasiswa yang memiliki motivasi tinggi lebih baik daripada mahasiswa yang memiliki motivasi berprestasi rendah jika diajar dengan model Student Active Learning. Pada sel (A1B1)(A2B1) menunjukan kemampuan menulis karya ilmiah mahasiswa yang memiliki motivasi berprestasi tinggi diajar dengan model Student Active Learning lebih baik daripada mahasiswa yang bermotivasi tinggi yang diajar dengan model TCL. Pada sel (A1B1)(A2B2) menunjukan kemampuan menulis karya ilmiah mahasiswa yang diajar dengan model Student Active Learning untuk yang memilki motivasi berprestasi tinggi secara signifikan lebih baik daripada mahasiswa yang diajar dengan model TCL yang memiliki motivasi berprestasi rendah.

\footnotetext{
${ }^{13}$ Chua, Wong, dan Chen, "Associations between Chinese Language Classroom Environments and Students' Motivation to Learn the Language.”
}

Kemudian, pada sel (A2B1)(A2B2), kemampuan menulis karya ilmiah mahasiswa yang diajar dengan model TCL yang bermotivasi tinggi secara signifikan lebih baik daripada mahasiswa yang bermotivasi rendah. Pada sel (A1B2)(A2B1) mahasiswa yang memiliki motivasi berprestasi rendah yang diajar dengan model Student Active Learning kemampuan menulis karya ilmiahnya tidak lebih baik daripada mahasiswa yang memiliki motivasi berprestasi tinggi yang diajar dengan model TCL. Pada sel (A1B2)(A2B2) kemampuan menulis karya ilmiah mahasiswa bermotivasi rendah yang diajar dengan model Student Active Learning secara keseluruhan tidak lebih baik daripada mahasiswa yang bermotivasi rendah yang diajar dengan model TCL.

Dengan demikian, dapat dikatakan bahwa kemampuan menulis karya ilmiah yang memiliki motivasi berprestasi tinggi lebih baik daripada yang memiliki motivasi berprestasi rendah. Selain itu mahasiswa yang diajar dengan model Student Active Learning dalam menulis karya ilmiah lebih baik daripada yang diajar dengan model TCL.

\section{SIMPULAN}

Berdasarkan hasil analisis tersebut, dapat disimpulkan: (1) Kemampuan menulis karya tulis ilmiah mahasiswa yang diajar dengan model Student Active Learning lebih baik daripada mahasiswa yang diajar dengan model TCL; (2) Kemampuan menulis karya tulis ilmiah mahasiswa yang memiliki motivasi berprestasi tinggi lebih baik daripada mahasiswa yang memiliki motivasi 
berprestasi rendah; (3) Ada interaksi antara model pembelajaran dan motivasi berprestasi dalam mempengaruhi kemampuan menulis karya tulis ilmiah.

\section{E. DAFTAR PUSTAKA}

Andayani. Statistik: untuk Pembelajaran Bahasa. Surakarta: UNS Press, 2014.

Andayani, M. Pd. Problema dan Aksioma: Dalam Metodologi Pembelajaran Bahasa Indonesia. Deepublish, 2015.

Asna, R. Hamidatul. "IMPLEMENTASI STRATEGI PEMBELAJARAN BERBASIS INKUIRI DENGAN SIKLUS BELAJAR 5E UNTUK MENINGKATKAN KETERAMPILAN BERPIKIR KRITIS." Jurnal Penelitian Pendidikan 14, no. 2 (2016). http://ejournal.upi.edu/index.php/ JER/article/view/3119.

Chua, Siew Lian, Angela FL Wong, dan DerThanq Chen. "Associations between Chinese Language Classroom Environments and Students' Motivation to Learn the Language." Australian Journal of Educational \& Developmental Psychology 9 (2009): 53-64.

Effendi, Mukhlison. "Integrasi

Pembelajaran Active Learning dan Internet-Based Learning dalam Meningkatkan Keaktifan dan Kreativitas Belajar." Nadwa 7, no. 2 (2016): 283-309.

Gupta, Deepti, dan Getachew Seyoum Woldemariam. "The influence of motivation and attitude on writing strategy use of undergraduate EFL students: Quantitative and qualitative perspectives." Asian EFL Journal 13, no. 2 (2011): 34-89.

Moghaddam, Mostafa Morady, dan Shirin Malekzadeh. "Improving L2 writing ability in the light of critical thinking." Theory and Practice in Language Studies 1, no. 7 (2011): 789-797.

Prayitno. Dasar teori dan praksis pendidikan. Jakarta: Grasindo, 2009.

Soemarsono. Strategi Belajar Mengajar. Surakarta: UNS Press, 2007.

Suharno, Sukardi, Hj. Cholidah H A, dan Suwalni S. Belajar Dan Pembelajaran II. Surakarta: UNS Press, 2000.

Suharsimi, Arikunto. Prosedur Penelitian Suatu Pendekatan Praktek. Jakarta: Rineka Cipta, 2006.

Thang, Siew Ming, Siew Ling Ting, dan Nurjanah Mohd Jaafar. "Attitudes and motivation of Malaysian secondary students towards learning English as a second language: A case study." $3 L$; Language, Linguistics and Literature, The Southeast Asian Journal of English Language Studies. 17, no. 1 (2011): 40-54.

Zubairi, Ainol Madziah, dan Isarji Sarudin. "Motivation to learn a foreign language in Malaysia." GEMA Online Journal of Language Studies 9, no. 2 (2009): 73-87. 